\title{
PENINGKATAN WAWASAN PENERAPAN MODEL PEMBELAJARAN BERORIENTASI HOTS (HIGHER ORDER THINKING SKILL) BAGI GURU MTS DAN MA
}

\author{
Nur Aini Puspitasari ${ }^{1}$, Syarif Hidayatullah ${ }^{2}$ \\ 1 Universitas Muhammadiyah Prof. DR. Hamka \\ korespondensi email: nur.aini.puspitasari@uhamka.ac.id \\ ${ }^{2}$ Universitas Muhammadiyah Prof. DR. Hamka \\ email: syarifbahagia@uhamka.ac.id
}

\begin{abstract}
This training aims to improve the ability of teachers to apply HOTS-oriented learning models. The method used in this activity is the method of lecture, discussion, and practice. The result of this activity is an increase in the number of teachers' understanding of HOTS-oriented learning models with a percentage of $88 \%$. Learning activities undertaken have led to high-level thinking (HOTS) reaching a percentage of $83 \%$. The lesson plans made have led to high-level thinking that reaches a percentage of $81 \%$. The learning approach has used SCL which reached a percentage of $84 \%$. Participants have applied HOTS-oriented learning model that includes discovery learning, problem based learning, and project based learning has reached $84 \%$. It can be concluded that this activity has increased the insight of teachers about HOTSbased learning practices theoretically and practically.
\end{abstract}

Keywords: HOTS learning; teacher; training.

\begin{abstract}
ABSTRAK
Pelatihan ini bertujuan untuk meningkat kemampuan guru dalam menerapkan model pembelajaran berorientasi HOTS. Metode yang digunakan didalam kegiatan ini adalah metode ceramah, diskusi, dan praktik. Hasil dari kegiatan ini adalah meningkatnya jumlah pemahaman guru terhadap model pembelajaran berorientasi HOTS dengan prosentase $88 \%$. Kegiatan pembelajaran yang dilakukan sudah mengarah kepada berpikir tingkat tinggi (HOTS) mencapai prosentase $83 \%$. RPP yang dibuat sudah mengarah pada berpikir tingkat tinggi yang mencapai prosentase 81\%. Pendekatan pembelajaran sudah menggunakan SCL yang mencapai prosentase $84 \%$. Peserta sudah mengaplikasikan model pembelajaran berorientasi HOTS yang mencakup discovery learning, problembased learning, dan project based learning sudah mencapai $84 \%$. Dapat disimpulkan kegiatan ini telah meningkatkan wawasan para guru tentang praktek pembelajaran bebasis HOTS secara teoritik dan praktik.
\end{abstract}

Kata Kunci: pembelajaran HOTS; guru; pelatihan.

\section{PENDAHULUAN}

Perubahan kurikulum 2013 ditingkat menengah dan atas membawa perubahan pada strategi mengajar guru di sekolah (Sutiyarti, Saragih, \& Sudarmianto, 2016). Hal ini terlihat dalam panduan praktik pelaksanaan 
pembelajaran yang mengarahkan pada kegiatan pembelajaran yang berpusat pada siswa (student center learning). Dalam panduan tersebut disebutkan bahwa kegiatan pembelajaran harus memajukan peserta didik dalam mengembangkan sikap, spritual, sosial, rasa ingin tahu, kreativitas, kerja sama, dengan kemampuan intelektual dan psikomotorik (Ariyana, Pudjiastuti, Bestary, \& Zamroni, 2018).

Pengembangan sikap, spritual, sosial, rasa ingin tahu, kreativitas, kerja sama, dengan kemampuan intelektual dan psikomotorik membutuhkan model pembelajaran yang inovatif dengan menggunakan cara berpikir tingkat tinggi pada siswa (Mardhiyana \& Sejati, 2016) (Wahid \& Karimah, 2018). Cara berpikir tingkat tinggi ini disebut dengan HOTS (Higher Order Thinking Skill). HOTS merupakan kemampuan berpikir kritis, berpikir kreatif, dan pemecahan masalah (Brookhart, 2010) (Syarifah, Usodo, \& Riyadi, 2018).

Dalam pembelajaran, HOTS memiliki peranan yang penting dalam kegiatan pembelajaran. Tujuan pembelajaran yang mengembangkan HOTS adalah untuk membekali siswa terampil memberi alasan dan membuat keputusan (Fanani \& Kusmaharti, 2014) (Anugrahana, 2018). Pentingnya HOTS dalam pembelajaran juga ditunjukkan oleh hasil penelitian Murray (2011) yang menyebutkan bahwa ketika siswa menggunakan HOTS maka siswa memutuskan apa yang harus dipercayai dan apa yang harus dilakukan, menciptakan ide-ide baru, membuat prediksi dan memecahkan masalah nonrutin.

Pemerintah juga mengharapkan peserta didik memiliki lima kompetensi yang dalam mencapai kecakapan abad 21. Lima kompetensi tersebut adalah berpikir kritis (critical thinking), kreatif dan inovasi (creative and innovative), kemampuan berkomunikasi (communication skill), kemampuan bekerja sama (collaboration), dan kepercayaan diri (confidence) (Redhana, 2019) (Sugiyarti, Arif, \& Mursalin, 2018). Untuk mencapai harapan pemerintah tersebut membutuhkan usaha guru dalam menyiapkan model pembelajaran yang akan diberikan kepada siswa (Prayogi \& Estetika, 2019).

Yayasan Kesejahteraan Umat Islam (YAKIIN) merupakan yayasan yang berada di ujung kota Tangerang dan ujung Jakarta. Yayasan tersebut berada di bawah naungan Kementerian Agama. Oleh karena itu jenjang yang ada di sekolah tersebut dimulai dari tingkat MI, MTs., dan MA. Yayasan Kesejahteraan Umat Islam juga memiliki pondok pesantren yang dikhususkan bagi kaum dhuafa. Di bawah naungan YAKIIN, sekolah MI sampai MA diberi nama Al Makmur. MTs. Al Makmur hanya memiliki satu lokal dari setiap angkatan dengan jumlah rata-rata 30 anak sehingga total siswa di MTs. Al Makmur berjumlah 90 anak. Sedangkan, di MA Al Makmur hanya terdapat 20 anak, dengan kelas $\mathrm{X}$ berjumlah 5 siswa, kelas $\mathrm{XI}$ berjumlah 5 siswa, dan kelas XII berjumlah 10 siswa.

Guru di MTs. dan MA Al Makmur berjumlah 25 orang, karena guru MTs. mengajar juga di MA. Guru tetap yayasan berjumlah 22 orang, sedangkan PNS hanya 3 orang. Guru di MTs. dan MA Al Makmur belum 
pernah mendapatkan pelatihan terkait model pembelajaran. Hal ini yang membuat startegi mengajar yang dilakukan masih konvensional, bahkan terkadang nilai siswa pada umumnya tidak mencapai KKM. Selain itu, siswa tidak diarahkan untuk berpikir kritis dalam penyelesaian masalah yang dihadapi dalam pembelajaran. Pembelajaran yang diberikan hanya mengarah pada kognitif yang bersifat pada memahami saja atau lingkup $C 1$.

Di sisi lain, guru lebih senang menggunakan metode ceramah saja. Tidak mengembangkan metode pengajaran dengan model-model pembelajaran yang mampu meningkatkan siswa dalam berpikir kritis. Dalam proses survey dan observasi, tim melakukan wawancara dan telah mengidentifikasi berbagai permasalahan pembelajaran yang ada di MTs dan MA Al Makmur. Salah satu permasalahan yang mengemuka adalah permasalahan tentang penerapan kurikulum 2013.

Secara kebijakan MTs dan MA Al Makmur telah mencanangkan konsep pembelajaran kurikulum 2013 sebagai salah satu upaya untuk menindaklanjuti edaran pemerintah tentang penerapan kurikulum tersebut. Namun, faktanya dalam pelaksanaan kegiatan pembelajara, guru masih menggunakan model pembelajaran yang masih berorientasi pada guru sehingga dapat dikatakan tidak menyentuh pada model pembelajaran yang mengembangkan HOTS.

Permasalahan ini mengemuka karena kurangnya pengetahuan mereka (guru) terkait model pembelajaran pada kurikulum 2013. Penyebabnya adalah guru tidak pernah mengikuti pelatihan kurikulum 2013. Hal ini mengakibatkan guru kesulitan dalam mengaplikasikan model pembelajaran yang terdapat pada kurikulum 2013.

Sebenarnya, apabila guru mengajarkan dengan model pembelajaran melalui pengembangan HOTS akan membuat siswa mampu berpikir kritis dan mampu menyelesaikan permasalahan dengan baik. Hal ini diperkuat dengan penelitian yang telah dilakukan oleh Lee yang mengemukakan bahwa HOTS diperlukan untuk menumbuhkan sikap postif dalam mengembangkan lingkungan melalui kemampuan mengembangkan ide-ide pemikiran dalam memecahkan masalah lingkungan(Yee, Lai, Tee, \& Mohamad, 2016).

Berdasarkan permasalahan maka dengan ini tim pengabdian kepada masyarakat perlu mengadakan workshop model pembelajaran untuk mengembangkan HOTS bagi guru di MTs. dan MA AI Makmur.

\section{METODE PELAKSANAAN}

Sebelum kegiatan pelatihan dilaksanakan, kegiatan pengabdian ini diawali dengan konsolidasi terlebih dahulu. Pada tahapan ini, ketua pelaksana melakukan konsulidasi berkaitan dengan pelatihan model pembelajaran berorientasi HOTS kepada MTs. dan MA AI Makmur di YAKIIN. Dalam proses ini dilakukan pula observasi melalui wawancara dan penyebaran angket untuk mengetahui bagaimana kemampuan guru tentang pemahaman terhadap 
kemampuan berpikir tinggi untuk siswa dan model pembelajaran berbasis HOTS di kedua jenjang tersebut.

Setelah menganalisis hasil dari konsolidasi, maka berikutnya adalah menentukan metode. Metode yang digunakan dalam pelaksanaan program PKM ini adalah dengan metode ceramah dan praktik. Artinya, para peserta dalam kegiatan ini mendengarkan arahan tim PKM kemudian harus mampu mempraktikkan berbagai arahan yang telah disampaikan oleh tim PKM. Praktik yang dilakukan adalah membuat RPP dengan model pembelajaran berorientasi HOTS berdasarkan mata pelajaran yang diampunya.

Dalam menjawab permasalahan mitra, tim pengabdian telah melaksanakan pengabdian masyarakat di MTs. dan MA Al Makmur Yayasan YKIIN. Kegiatan ini diikuti oleh 18 orang guru. Pelaksanaan tersebut dilakukan sebanyak 2 kali pertemuan. Narasumber dalam kegiatan pelatihan ini adalah Nur Aini Puspitasari, M.Pd. dan Syarif Hidayatullah, M.Pd.

\section{HASIL DAN PEMBAHASAN}

Kegiatan berjalan dengan lancar tanpa gangguan apapun. Hal ini ditunjukkan pada keseriusan pihak sekolah yang turut berperan demi kelancaran kegiatan pelatihan ini. Keseriusan tersebut berbentuk kebijakan meliburkan siswanya ketika para guru sedang mengikuti pelatihan. Karena pihak sekolah sudah mengeluarkan kebijakan meliburkan siswanya maka para guru pun berantusias dalam mengikuti pelatihan ini. Hal ini dapat terlihat pada pembuatan RPP yang sudah mengarah pada model pembelajaran berorientasi HOTS.

Kegiatan hari pertama adalah pembukaan oleh ketua tim PKM yaitu Nur Aini Puspitasari, M.Pd. Ketua tim PKM menyampaikan tujuan kegiatan pelatihan model pembelajaran berorientasi HOTS yaitu agar para guru MTs. dan MA Al Makmur dapat memahami dan menerapkan model pembelajaran berorientasi HOTS sehingga mampu membuat RPP dan membuat soal yang beroreintasi HOTS. Selain itu, agar siswa di MTs. dan MA Al Makmur dapat berpikir tinggi atau kritis terhadap permasalahan kehidupan yang dihadapi melalui pelajaran-pelajaran yang diberikan di sekolah. Setelah pembukaan dilanjutkan dengan sambutan Kepala MTs. Al Makmur oleh Muhammad Sirri, S.Pd.I. Beliau menyampaikan terima kasih kepada Tim PKM UHAMKA karena sudah berbagi ilmu pengetahuan tentang model pembelajaran berorientasi HOTS yang menjadi pangkal keberhasilan guru dalam mengajar dan keberhasilan siswa dalam belajar. Besar harapan beliau, para guru dapat menerapkan materi yang sudah disampaikan oleh tim PKM UHAMKA.

Kegiatan selanjutnya adalah penyampaian materi berpikir tingkat tinggi (HOTS) dan menganalisis SKL dan Kompetensi Inti. Pada kegiatan ini dihadari oleh 18 orang guru. Sebelum kegiatan dimulai tim PKM UHAMKA memberikan blocknote, kertas folio, dan pulpen. Materi tentang berpikir tingkat tinggi (HOTS) dan menganalisis SKL dan Kompetensi Inti dipaparkan oleh Nur Aini Puspitasari, M.Pd. Ketika ditanya tentang model pembelajaran dan 
pendekatan pembelajaran yang dilakukan beberapa guru menjawab menggunakan pendekatan TCL (teaching center learning) pembelajaran masih terfokus pada guru dan bukan pada siswanya. Selain itu, pemahaman tentang apa itu HOTS dan bagaimana menganalisis SKL dan kompetensi inti, para guru menjawab pemahaman mereka terkait hal tersebut rata-rata baru $51 \%$. Karena sebelumnya tidak ada pelatihan terkait dengan HOTS dan analisis SKL dan kompetensi inti.

Setelah dipaparkan materi tentang HOTS dan level berpikir yang harus dimiliki siswa, para guru tersebut baru memahaminya. Para guru merasa betapa pentingnya mengintegrasikan HOTS dalam model pembelajaran dan soal-soal yang dibuat karena mengidentifikasi zaman yang semakin canggih.

Setelah narasumber memaparkan tentang konsep HOTS, para guru atau peserta pelatihan menganalisis SKL dan KI yang sudah dibuat di RPP mereka. Hasilnya adalah $82 \% \mathrm{SKL}$ dan $\mathrm{KI}$ yang dibuat belum memenuhi standar sehingga memengaruhi KKM, dan siswa pada umumnya belum mencapai KKM secara maksimal.

Hasil yang didapat setelah mengikuti pelatihan pada tahap pertama tentang konsep berpikir tingkat tinggi dan analisis SKL dan KI terdapat perubahan yang signifikan. Perubahan tersebut dapat terlihat ketika tim PKM UHAMKA melakukan monitoring dan evaluasi setelah pelatihan. Hasilnya adalah kegiatan pembelajaran yang dilakukan sudah mengarah kepada berpikir tingkat tinggi (HOTS) dengan melakukan 4C, yaitu creative, critical thinking, communication, and collaboration yang mencapai prosentase $83 \%$ dari sebelumnya hanya $43 \%$. Kemudian RPP yang dibuat sudah mengarah pada berpikir tingkat tinggi yang mencapai prosentase $81 \%$ yang sebelumnya hanya $51 \%$ sehingga ada kenaikan $30 \%$. Selain itu, pendekatan pembelajaran sudah menggunakan SCL yang mencapai prosentase $84 \%$ yang sebelumnya hanyalah $25 \%$ terjadi peningkatan $59 \%$ dari sebelumnya.

Kegiatan pelatihan tahap kedua adalah model pembelajaran berorientasi HOTS, yang disampaikan oleh Syarif Hidayatullah, M.Pd., pada Rabu, 7 Agustus 2019. Pada pelatihan tahap ini jumlah peserta tetap sama dengan tahap pertama yaitu 18 orang. Pemaparan pada tahap ini adalah puncak dari kegiatan pengabdian masyarakat yang diberikan. Materi model pembelajaran berorientasi HOTS yang disampaikan Pak Syarif Hidayatullah, M.Pd. berupa model pembelajaran discovery learning, problem based learning, dan project based learning.

Sebelum memulai materi, narasumber memberikan kuesioner apakah peserta sudah memahami tentang model pembelajaran berorientasi HOTS, peserta menjawab $51 \%$ belum memahami model pembelajaran berorientasi HOTS. Selain itu, $50 \%$ peserta juga belum mengaplikasikan model pembelajaran berorientasi HOTS karena Model pembelajaran berorientasi HOTS yang mencakup discovery learning, problem based learning, dan project based learning belum semua model ini diterapkan oleh guru, ada yang baru satu jenis saja yang digunakan. Tetapi setelah mengikuti pelatihan ini 
peserta sudah mengaplikasikan model pembelajaran berorientasi HOTS yang mencakup discovery learning, problem based learning, dan project based learning sudah mencapai $84 \%$ dan ketiga model yang dipaparkan oleh narasumber sudah dapat diaplikasikan di MTs. dan MA Al Makmur sesuai dengan mata pelejaran yang diampu. Sedangkan, $16 \%$ yang belum mengaplikasikan model pembelajaran berorientasi HOTS karena terkendala oleh faktor usia, karena terlalu nyaman mengajar dengan metode ceramah saja.

Pada materi model pembelajaran berorientasi HOTS ini dapat dikatakan berhasil karena sebelum mengikuti pelatihan ini peserta menjawab $51 \%$ belum memahami model pembelajaran tersebut, tetapi setelah melalui pelatihan ini peserta sudah mencapai $88 \%$ untuk pemahaman model pembelajaran berorientasi HOTS.

Setelah mengikuti pelatihan ini pula, pendekatan yang digunakan oleh guru di MTs. dan MA Al Makmur sudah mulai berubah yaitu SCL (student center learning). Para guru tersebut sudah mulai menyadari betapa pentingnya pendekatan pembelajaran yang diberikan kepada siswa karena akan berpengaruh pada keberhasilan pembelajaran.

\section{KESIMPULAN}

Pelaksanaan kegiatan pengabdian masyarakat ini berhasil. Hal ini ditandai dengan peserta pelatihan yang telah mengalami peningkatan wawasan penerapan model pembelajaran berorientasi HOTS dengan prosentase $88 \%$. Kegiatan pembelajaran yang dilakukan sudah mengarah kepada berpikir tingkat tinggi (HOTS) dengan melakukan 4C, yaitu creative, critical thinking, communication, and collaboration yang mencapai prosentase $83 \%$. RPP yang dibuat sudah mengarah pada berpikir tingkat tinggi yang mencapai prosentase $81 \%$ yang sebelumnya hanya $51 \%$ sehingga ada kenaikan $30 \%$. Pendekatan pembelajaran sudah menggunakan SCL yang mencapai prosentase $84 \%$ yang sebelumnya hanyalah $25 \%$ terjadi peningkatan $59 \%$ dari sebelumnya. Peserta sudah mengaplikasikan model pembelajaran berorientasi HOTS yang mencakup discovery learning, problem based learning, dan project based learning sudah mencapai $84 \%$ dan ketiga model yang dipaparkan oleh narasumber sudah dapat diaplikasikan di MTs. dan MA Al Makmur sesuai dengan mata pelajaran yang diampu.

\section{UCAPAN TERIMA KASIH}

Kegiatan ini dapat berlangsung dengan baik berkat kerja sama dari berbagai pihak. Dalam kesempatan ini, tim mengucapkan terima kasih kepada Lembaga Pengabdian dan Pemberdayaan Masyarakat Universitas Muhammadiyah Prof. DR. HAMKA yang telah membiayai pelaksanaan kegiatan ini. Selain itu, ucapan terima kasih juga disampaikan kepada Yayasan Yakiin yang telah memfasilitasi pelaksanaan kegiatan ini. 


\section{DAFTAR RUJUKAN}

Anugrahana, A. (2018). Tinjauan Deskriptif Penerapan Higher Order Thinking dan Problem-Based Learning Pada Mata Kuliah Geometri Berdasarkan Kemampuan Matematika Mahasiswa. Scholaria: Jurnal Pendidikan Dan Kebudayaan, 8(2), 142-156. https://doi.org/10.24246/j.js.2018.v8.i2.p142-156

Ariyana, Y., Pudjiastuti, A., Bestary, R., \& Zamroni. (2018). Buku Pegangan Pembelajaran Berorientasi pada Keterampilan Berpikir Tingkat Tinggi (Program Peningkatan Kompetensi Pembelajaran Berbasis Zonasi). (Sajidan \& R. Mohandas, Eds.). Jakarta: Direktorat Jenderal Guru dan Tenaga Kependidikan, Kementerian Pendidikan dan Kebudayaan RI. Retrieved from http://repositori.kemdikbud.go.id/11316/1/01._Buku_Pegangan_Pembe lajaran_HOTS_2018-2.pdf

Brookhart, S. M. (2010). How to assess higher order thinking skills in your classroom. Alexanderia: ASCD.

Fanani, A., \& Kusmaharti, D. (2014). Pengembangan pembelajaran berbasis HOTS (Higher Order Thinking Skill) di Sekolah Dasar Kelas V. Jurnal Penndidikan Dasar, 1(9), 1-11. https://doi.org/doi.org/10.21009/JPD.091.01

Mardhiyana, D., \& Sejati, E. O. W. (2016). Mengembangkan Kemampuan Berpikir Kreatif dan Rasa Ingin Tahu Melalui Model Pembelajaran Berbasis Masalah. In PRISMA, Prosiding Seminar Nasional Matematika (pp. 672-688). Semarang: Universitas Negeri Semarang. Retrieved from https://journal.unnes.ac.id/sju/index.php/prisma/article/view/21686

Murray, E. C. (2011). Implementing higher-order thinking in middle school mathematics classrooms. University of Georgia.

Prayogi, R. D., \& Estetika, R. (2019). Kecakapan Abad 21 : Kompetensi Digital Pendidik Masa Depan. Jurnal Manajemen Pendidikan, 14(2), 144-151. https://doi.org/10.23917/mp.v14i2.9486

Redhana, I. W. (2019). Mengembangkan Keterampilan Abad Ke-21 Dalam Pembelajaran Kimia. Jurnal Inovasi Pendidikan Kimia, 13(1), 22392253. Retrieved from https://journal.unnes.ac.id/nju/index.php/JIPK/article/view/17824

Sugiyarti, L., Arif, A., \& Mursalin. (2018). Pembelajaran Abad 21 di SD. In Prosiding Seminar dan Diskusi Nasional Pendidikan Dasar (pp. 439444). Jakarta: Universitas Negeri Jakarta. Retrieved from http://journal.unj.ac.id/unj/index.php/psdpd/article/view/10184

Sutiyarti, U., Saragih, F. A., \& Sudarmianto, D. (2016). Dampak Implementasi Kurikulum 2013 Terhadap Jam Pelajaran Bahasa Jepang Pada Tingkat SMA/MA Di Wilayah Jawa Timur. Paramasastra: Jurnal Ilmiah Bahasa Sastra Dan Pembelajarannya, 3(1), 76-94. https://doi.org/10.26740/parama.v3n1.p\%25p 
Syarifah, T. J., Usodo, B., \& Riyadi. (2018). Higher Order Thingking (Hot) Problems To Develop Critical Thinking Ability and Student Self Efficacy in Learning Mathematics Primary Schools. In Social, Humanities, and Educational Studies (SHEs): Conference Series (Vol. 1, pp. 917-925). Surakarta: Universitas Sebelas Maret. https://doi.org/10.20961/shes.v1i1.23676

Wahid, A. H., \& Karimah, R. A. (2018). Integrasi High Order Thinking Skill (HOTS) dengan Model Creative Problem Solving. Modeling: Jurnal Program Studi PGMI, 5(1), 82-98. Retrieved from http://jurnal.stitnualhikmah.ac.id/index.php/modeling/article/view/161

Yee, M. H., Lai, C. S., Tee, T. K., \& Mohamad, M. M. (2016). The Role of Higher Order Thinking Skills in Green Skill Development. EDP Sciences, 70(5001), 1-5. 